Women on corporate boards around the world: Triggers and barriers

\author{
Amon Chizema \\ University of Birmingham \\ Birmingham Business School \\ B15 2TY, Edgbaston, Birmingham, UK \\ $\&$ \\ Dzidziso Samuel Kamuriwo \\ Cass Business School \\ City University London, \\ 106 Bunhill Row, EC1Y 8TZ, UK \\ $\&$ \\ Yoshikatsu Shinozawa \\ SOAS, University of London \\ London WC1H 0XG, London, UK
}




\title{
Women on corporate boards around the world: Triggers and barriers
}

\begin{abstract}
One of the institutions in which the gender gap remains a contestable issue is the board of directors, where the proportion of female directors is still low. While some countries have achieved higher proportions of female directors on their corporate boards, others have not registered even a single one. Drawing on social role theory, that places emphasis on traditional gender activities, this study starts by arguing that board directorship is an agentic role and more suitable for men. The study shows that key social institutions have the potential to alleviate such stereotypical attitudes or to maintain the status quo. Employing a robust statistical technique in two-stage least squares $(2 S L S)$, this study finds that the representation of women in other key national institutions, such as in politics, positively affects the appointment of female directors on boards. On the other hand, religiosity has a negative causal effect on female board appointments.
\end{abstract}

Key words: female directors, board of directors, social role theory, social institutions 


\section{Introduction}

The lack of female representation on corporate boards has attracted the attention of academics (Hillman, Shropshire \& Cannella, 2007), policy makers (OECD, 2009), practitioners and civil society (Catalyst, 2007). Part of this interest derives from the observed and perceived importance of achieving gender equity in societal and political leadership (Bullough, Kroeck, Newbury, Kundu \& Lowe, 2012) as well as in firms (Nielsen \& Huse, 2010).

Explanations for the representation of women in elite leadership roles traditionally focused on the idea that a lack of qualified women created a "pipeline problem". This shortage of qualified women has been ascribed to a variety of causes, including women's family responsibilities (Greenhaus \& Parasuraman, 1999) and inherited tendencies for women to display fewer of the traits and motivations that are necessary to attain and achieve success in high-level positions (Browne, 1999; Carter, D'Souza, Simkins \& Simpson, 2010; Goldberg, 1993).

Another explanation resides in gender role attitudes, "the opinions and beliefs about the ways that family and work roles do and should differ based on sex" (Harris \& Firestone, 1998: 239). Indeed, some societies hold traditional gender role attitudes and believe in a clear division of labor, where "men must be more concerned with economic and other achievements, while women must be concerned with taking care of people in general and of children in particular" (Hofstede, 2001: 280). In contrast, non-traditional gender role attitudes in some societies suggest a less distinct genderrole-based division of labor, where men and women share various responsibilities (Van Yperen \& Buunk, 1991). We argue that, this view, consistent with insights from social psychology on gender differences and social roles, (Wood \& Eagly, 2012) may provide better understanding of gender disparity on corporate boards. 
Social role theory potentially undergirds the lack of female representation, positing that differences in societal roles lead men and women to demonstrate and value different types of interpersonal behaviors (Eagly, 1987; Eagly \& JohannesenSchmidt, 2001). The perception is that men tend to value and engage in more assertive, competitive and agentic behaviors, whereas, because women traditionally occupy more caretaking roles, they tend to value and engage in more communal behaviors (Eagly, 1987; Koenig, Eagly, Mitchell \& Ristikari, 2011).This common placement of women and men into prescribed roles produces gender stereotypes by observing their behavior in such roles. Such stereotypical perceptions are shared by individuals in a society, from where they derive their legitimacy, and are thus culturally consensual.

Applying the foregoing reasoning, in the context of the workplace and indeed the boardroom, women are, therefore, more likely than men to hold positions at low levels in hierarchies of status and authority and are less likely to be at the highest levels of organizational hierarchies (Heilman, 2001; Wood \& Eagly, 2012) where agency is expected.

Notwithstanding the power and commonality of gender role perceptions, there is evidence that in some hunter-gatherer societies, even men sometimes perform substantial infant care (Fouts, 2008). Moreover, in many industrialized societies some men pursue female-dominated professions such as nursing or social work (Sayer, Cohen \& Casper, 2004). The fact that men and women sometimes engage in gender atypical activities suggests flexible behavior that is not rigidly differentiated by sex (Wood \& Eagly, 2012), but one that is shaped by situational/contextual demands. This implies that both sexes can be socially sensitive or aggressive, given appropriate socialization and support from the social environment, where beliefs and practices are 
shared and subsequently modified (Richerson \& Boyd, 2005; Tennie, Call \& Tomasello, 2009).

In addition, the fact that gender roles are a social construction, manifest in stereotypes (Eagly \& Karau, 2002), suggests that these [stereotypes] could be broken down only by genuine social change. Such social change could see occupational and domestic-work segregation weakened, consequently changing the perception of women and men roles with an inclination to equality. Arguing for the inevitable rise of women's status, Jackson (1998) emphasizes that changes in economic, cultural and political systems over the years alleviated women's disadvantages by improving their access to positions. As economies got better, production and power once the preserve of the household (where men played a superior role) moved to economic and political organizations, thus reducing men's dominance. This observation underscores the salience and role of social institutions in facilitating or inhibiting gender roles.

However, countries' economic, political and cultural institutions have progressed at differing rates. As such, at the country level, institutional environments, and by extension, social institutions vary, suggesting different levels in the potential to either minimize or enhance gender roles and stereotypes. Indeed, Jackson (1998) posits that the timing, rate and form of specific changes around issues of gender inequality have varied considerably across countries.

In the context of this study, we argue that some countries would, therefore, have higher proportions of female directors on boards than others. Drawing on social role theory, and in particular considering the extent to which gender role attitudes differ among societies, this study seeks to explore the institutional factors that potentially lead to varying levels of female board appointments across countries. 
Two streams of literatures are of relevance to our study. The first stream relates to the association between gender role attitudes and critical issues related to the workplace environment for women (Eyring \& Stead, 1998; Kirchmeyer, 2002). The second examines the presence of women on boards within particular country settings including the UK (Conyon \& Mallin, 1997; Singh \& Vinnicombe, 2004), the US (Peterson \& Philpot, 2007) Switzerland (Ruigrok, Peck \&Tacheva, 2007) and Norway (Nielsen \& Huse, 2010).

While much has been written about this subject in single country studies, only a few researchers (Grosvold \& Brammer, 2011; Terjesen \& Singh, 2008) have focused their attention on cross-national studies. Using data from 38 countries over the years 2001 to 2007, Grosvold, \& Brammer (2011) place countries in clusters defined by national institutional systems, akin to varieties of capitalism (Hall \& Soskice, 2001; Jackson \& Deeg, 2008), to understand the proportion of female directors on boards. On their part, Terjesen \& Singh (2008) find that countries with higher representation of women on boards are more likely to have women in senior management and equal ratios of male to female pay.

Our paper offers several contributions. First, this study employs a social psychology lens i.e. social role theory to understand a topical corporate governance issue on board gender diversity, not only in a single country but across forty-five countries. Indeed, this work builds on previous studies, contributing to the growing literature on gender diversity and the appointment of women to upper echelons of firms across the world. As such, this study emphasizes the salience and diversity of the institutional environments obtaining around the world (Aguilera \& Jackson, 2003). 
Second, our study is interdisciplinary, bringing together various strands of literature: international business, corporate governance, gender, politics and development studies. Such an approach facilitates better understanding of the subject at hand, providing more awareness of the developments in various disciplines. Third, this study improves our understanding of the macro-factors that determine gender diversity of corporate boards. Fourth, this paper potentially helps companies to understand the institutional environment in which they operate and more importantly how to react to it when making board appointment decisions.

\section{Theory and hypotheses}

According to social role theory, the perceived differences in the behavior of women and men originate in the contrasting distributions of men and women into social roles (Eagly, 1987). Thus, men and women are thought to possess attributes that equip them for sex-typical roles. For example, men are more likely than women to be employed, especially in authority positions, and women are more likely than men to fill caretaking roles at home as well as in employment settings (Eagly \& Wood, 2012). As such, gender differences and similarities in behavior reflect consensually-shared gender role beliefs or gender stereotypes that in turn represent society's perceptions of men's and women's social roles in the community in which they live.

Sharing these beliefs as people in a society, gender roles get established and accepted by individuals who constitute the community. Individually, people act on their beliefs, recognize that others think similarly, and know that others act on this shared knowledge (Ridgeway, 2006). As such, these typical attributes tend to be seen as desirable and admirable for each sex, adding prescriptiveness to and consensus on 
gender roles. Because these social roles are consensual, societies equip men and women by undertaking extensive socialization to promote personality traits and skills that facilitate role performance.

Thus, drawing mainly on social role theory, extant research suggests that men and women respond differently to various aspects of social relationships, which can be categorized as either communal or agentic (Eagly, 1987; Koenig, et al., 2011). The communal dimension is interpersonally oriented and broadly described as a concern for the welfare of others (e.g., nurturing, sympathetic, friendly), with women scoring higher on this dimension than men (Eagly, 1987, 2009; Spence \& Buckner, 2000). While these stereotypes may be perceived as positive in content, however, they serve to justify women's continued acceptance of their traditional social roles (Glick \& Fiske, 2001). Moreover, they can undoubtedly possess negative consequences for women, as they are suggested to undermine perceptions of competence and power (Jost \& Kay, 2005).

On the other hand, the agentic dimension is task-oriented and defined by independent, masterful, and assertive tendencies (e.g., competitive, ambitious, dominating), with men scoring higher on this dimension than women (Eagly, 1987; Eagly \& Johannesen-Schmidt, 2001; Spence \& Buckner, 2000).

Some literature suggests that the stereotypically female characteristic of nurturance is valued less in the labor market than the stereotypically male characteristic of aggressiveness (Kilbourne \& England, 1996). Furthermore, women who have internalized traditional beliefs about how women should act may be less likely to behave assertively when they do not get promotion (Betz \& Fitzgerald, 1987). Both situations suggest that women with traditional gender role orientations 
would aspire less to gain board seats, while those with no traditional role orientations would be more inclined to gaining board appointments.

\section{Social institutions and gender role attitudes}

The fact that societies undertake socialization to enable men and women to fit in their prescribed roles, suggests that the institutional environment plays a significant part in defining gender role beliefs. This also suggests that there should be variation from one context to the other or between countries in terms of gender role attitudes and consequently women's access to key positions of authority.

Several studies have examined how countries differ in their institutional environments, leading to differences in practices and how such practices are interpreted by their respective social institutions (Aguilera \& Jackson, 2003; Kostova, 1999). For example, Kostova (1999) provides a compelling explanation on how a country's institutional profile is configured. The country institutional profile refers to "the set of all relevant institutions that have been established over time, operate in that country, and get transmitted into organizations through individuals" (Kostova, 1997: 180). The country institutional profile can be understood through three components namely, regulatory (e.g., laws and rules) cognitive (e.g., shared knowledge), and normative (e.g., attitudes, values and norms). The three components form three pillars of Scott's (1995) conception of social institutions.

As mentioned earlier, societies develop gender role attitudes, and people conform to such expectations through the way they behave both at home and work. Gender role attitudes are, therefore, a function of social institutions that uphold and transmit norms and values. This suggests that if social institutions change, gender role attitudes may follow suit. We argue, therefore, that countries with social institutions that place or facilitate less emphasis on traditional gender roles are likely to witness 
equality or near equality of opportunities by both men and women and vice versa. Indeed, research suggests that the salience of a particular stereotype may be dictated by context (Turner, Hogg, Oakes, Reicher, \& Wetherell, 1987; van Knippenberg, van Twuyver, \& Pepels, 1994). For instance, the stereotypical belief that women do or do not possess the qualities to be board directors may depend on the institutional environment. In the context of this study such beliefs may vary from one country to the next.

In this paper, we consider three important social institutions that have the potential to differentially shape gender role attitudes across countries, namely the political system (representation of women in parliament), the economic system and the degree of religiosity. Of the many social institutions, the gender literature suggests that the three in our study are arguably the most important factors of the institutional environment for developing the taken-for-granted elements of gender roles (Lindsey, 2005). Moreover, while not tested empirically, Jackson's (1998) thesis is that the evolution of economic and political systems explains the levels of gender inequality across countries. In the sections below, we discuss the link between these key social institutions and the presence of women on boards, providing our hypotheses in the process.

\section{Representation of women in politics}

We argue that it is plausible that gender stereotypes and their attendant effects could be observed at varying levels in different institutions within a given period of time. Specifically, political science literature shows that progress by women in politics and government was made earlier (Skjeie, 1991) and far exceeds that made in business. For example, in Norway the proportion of women in the Norwegian government and politics has since been higher, compared to other areas of the labor 
market such as academia and the private sector (Seierstad \& Healy, 2012; Seierstad \& Opsahl, 2011). However, such other areas, in particular, the private sector are catching up. We argue that this development is partly due to the fact that the successful entry of women in politics and government encourages other women who are in business to aim higher too, putting themselves forward for board seats.

This observation illustrates two important issues. First, it lends support to the central argument in this paper that social institutions vary in their potential to break down traditional gender social roles. Second, it shows that the breaking down of gender role stereotypes in one part of society could serve as a reference point to initiate social change in others. In this case, the breaking down of gender role stereotypes is catalyzed by social learning, a process by which an individual learns from his neighbors' experiences or social referents about their previous decisions and outcomes, behavior or practices (Munshi, 2003). Here, the importance and motivation of learning from social referents, via observation, imitation, and modelling cannot be underestimated (Bandura, 1977). This suggests that much of human behavior is learned through the influence of example. In the context of this study, seeing more women in government or politics should increase the tendency of the observer (women in business) to aspire for equivalent roles in business. Consequently, this effectively reduces the traditional gender role attitudes by both men and women in the corporate sector.

There are similarities between the two groups (in politics and business) of women. For instance, like board directors, members of parliament or government ministers are elected or appointed on the basis of their knowledge, skills and experience. Moreover, there have been calls for both business and politics to appoint women to the highest echelons of leadership (Seierstad \& Healy, 2012). 
With such similarities in the backgrounds for the two groups of women and in the requisite qualifications for the tasks, it would be expected that success achieved by one part is likely to be an encouragement for the other. We argue, therefore, that countries that have achieved success i.e. higher proportions of female members in high level politics have managed to reverse traditional gender role attitudes in one area and are more likely to repeat this in others, including on corporate boards.

We, therefore, suggest that the extent to which women are represented in politics may determine the proportion of female directors in other key institutions, including on corporate boards.

Hypothesis 1. The level of women's representation in politics will positively impact on the prevalence of women on boards of corporate directors.

\section{Economic freedom}

Earlier, we argued that gender stereotypes are likely to be broken down through social change, whereby occupational and domestic-work segregation weaken, thus changing the perception of men and women attributes. We argue that economic development has the potential to provide this social change. Indeed, economic growth increases the number of job vacancies that need to be filled, at all levels.

Two things are likely to happen that would mean more women in employment and potentially in high-ranking posts. The first is that an expanding economy suggests that with time there would be a shortage of skilled labor from the traditional sources. Thus, where companies had been recruiting more men for executive posts, they may find difficulties to carry on doing this as the competition intensifies. Companies would then seek to recruit from alternative sources, hence the appointment of women across all levels of the company hierarchy. Secondly, because of the high demand for labor that results from a growing economy, companies may offer higher wages thus 
encouraging more women to take paid jobs as opposed to staying home. Both scenarios carry significant and positive changes in the context of gender role attitudes and subsequent appointment to the upper echelons of the organization. Indeed, increased participation in the workforce by women leads to the adoption of new gender role attitudes as more women work alongside men.

We argue, therefore, that countries that are more economically developed are more likely to have less traditional gender role attitudes, suggesting that more women would be appointed to corporate boards. As Matland (1998: 114) notes: "Development leads to weakening of traditional values, decreased fertility rates, increased urbanization, greater educational and labor force participation for women, and attitudinal changes in perceptions of the appropriate roles for women." In the context of our study, we therefore expect that women are more likely to be appointed as directors on boards in a country that has developed economic institutions. We, therefore, hypothesize:

Hypothesis 2. The institutional development of a country's economic environment is positively impacts on the prevalence of women on boards of corporate directors.

\section{Religiosity}

Religions, the shared set of beliefs, activities, and institutions based on faith in supernatural forces (Stark \& Bainbridge, 1985), are important social institutions in most societies (Iannaccone, 1991). Consequently, religious doctrine has been known to characterize variation in country attitudes in general, thus may, in particular, play an important role in shaping attitudes toward women's place in leadership.

With reference to the longstanding issue of gender inequality, scholars agree on the continued role of religion in maintaining the status quo (Bendroth, 1993; Woodhead, 2006). In fact, religion's central role in consolidating gender differences 
and inequality was recognized, explored and critiqued by nineteenth-century feminists like Elizabeth Cady Stanton (Woodhead, 2006). In recent years, studies have found that levels of gender equality across different countries are related to cultural factors above all, religiosity (Inglehart \& Norris, 2003). Such studies show, too, that crosssectional differences in support for gender equality vary even between societies at similar levels of development, and depend upon the degree of religiosity. This has prompted Inglehart \& Norris (2003) to conclude that, 'religion matters, not only for cultural attitudes but for the opportunities and constraints on women's lives, such as the ratio of females to males in educational enrolment, the female adult literacy rate, the use of contraception as well as for opportunities for women in the paid workforce' (2003: 69). Religion, therefore, matters for opportunities for women to gain board appointments. This is not, however, a question of religious men simply imposing religious attitudes upon women, for traditional gender values and roles tend to be shared by both sexes in the same type of society (Woodhead, 2007).

In general, religious institutions often prescribe what is considered right and wrong, acceptable and unacceptable (Turner, 1997) and tend to be conservative or patriarchal in their views about the place of women, both in the church hierarchy and in society (Kenworthy \& Malami, 1999). We add that ${ }^{1}$ religions can and do promote gender stereotypes by their portrayal of ideal relations between the sexes (e.g., veneration of Mary, mother of Jesus; no women in Catholic priesthood). Indeed, previous research suggests that most religions encourage and reinforce values consistent with traditional gender roles (Lindsey, 2005; Sjoberg, 2004) "that include separate subordinate positions for women" (Banaszak \& Plutzer, 1993: 149).

\footnotetext{
${ }^{1}$ We are grateful to one of our reviewers for this suggestion.
} 
Given the arguments we make above, therefore, most religions tend to promote distinct gender roles, and consistent with social role theory most societal members use religion to justify such arrangements. Therefore, countries with higher levels of religiosity are more likely to have individuals exposed to views promoting traditional gender roles (Lindsey, 2005). From such societies, it is more likely that firms, through their agents (CEOs, Chairmen and nomination committees), view traditional gender roles as the norm, suggesting fewer board appointments for women.

Following these arguments we propose that:

Hypothesis 3. The degree of religiosity in a society relates negatively to the proportion of female directors on the board.

\section{Methodology}

\section{Sample and data}

Our study explores the social triggers and barriers that explain the prevalence of women on corporate boards across the world. To achieve our objectives, we use a sample of 45 countries, taking an average of observations over seven years from 2007 through 2013. These countries are drawn from all the continents, however, in varying proportions. Table 1 shows the distribution of the countries by region. The highest number of countries is from Europe (16), followed by Asia (13). Table 1 below shows the sample of countries in six regions.

\section{Insert Table 1 about here}




\section{Measures}

\section{Dependent variable}

Our dependent variable is the average percentage of women on boards (womboard) for the years 2007 through 2013 in a given country. Data on this variable was collected from the annual reports prepared by GMI. For example, the GMI report titled GMI Ratings' 2013 Women on Boards Survey contains data for the 45 countries for the years 2008 through 2013. Data for 2007 was collected from surveys carried out by Catalyst. We triangulated this data by using McKinsey \& Company Report 1 abovefor the year 2007. Since 2007, McKinsey has been researching the business case for increasing the number of women in senior management roles, published in the series titled Women Matter. While not all the countries in our sample are covered in this report, we used the ones provided therein to verify the reliability of the data provided by Catalyst.

\section{Independent variables}

Our approach involves generating a set of independent variables that capture key social institutions namely economic, political and religion. For Hypothesis 1 we use the average percentage of women in parliament (womparly) for the years 2007 through 2013. We collect data for this variable from the World Bank Development Indicators, published on their website.

For Hypothesis 2 we use the logarithm of the average gross domestic product (lngdp) per capita as the basis of our measurement for level of economic development. We also collect data for this variable from the World Bank Development Indicators, published on their website.

For Hypothesis 3, we use the religiosity index to proxy for a country's beliefs and cultural values. The religiosity index represents the percentage of the population 
who self-describe themselves as a 'religious person' in the question worded as: Irrespective of whether you attend a place of worship or not, would you say you are a religious person, not a religious person or a convinced atheist? Data on religiosity is sourced from WIN-Gallup International and from the World Religion Database (WRD). The former is the principal source while the latter was used to triangulate the data. The WIN-Gallup International 'Religiosity and Atheism Index' which measures global self-perceptions on beliefs is based on interviews with more than 50, 000 men and women selected from countries across the globe (WIN-Gallup International, 2012).The World Religion Database contains detailed statistics on religious affiliation for every country of the world. It provides source material, including censuses and surveys, as well as estimates for every religion, offering a definitive picture of international religious demography.

\section{Control variables}

We control for a specific cultural dimension with a direct link to gender roles namely masculinity (Hofstede, 1988). According to Hofstede, (2001: 297), "masculinity stands for a society in which social gender roles are clearly distinct: men are supposed to be assertive, tough, and focused on material success; women are supposed to be more modest, tender, and concerned with the quality of life." Consistent with social role theoretical arguments, societies with high scores of masculinity are less likely to have more female directors.

In our second regression model, we also control for region to capture regional characteristics. We use broad regional classifications as follows Europe, Eastern Europe, Middle East and Africa, South America, North America and Asia. With 6 regions, we model 5 dummy variables. Region is considered an extremely broad ideological variable (Paxton, 1997), so ideally, we would explain any impact of 
regionalism with the other variables included in the model. If region has a direct impact on the proportion of women on boards after the other variables are included, then we assume that would be an indication of some cultural variation not explained within the model.

\section{Model specification}

Using STATA we estimate the following regression:

Womboard $_{i}=\beta_{0}+\beta_{1}$ womparly $_{i}+\beta_{2} \operatorname{lnGDP}_{i}+\beta_{3}$ relig $_{i}+\beta_{4}$ mascul $_{i}+$ $e_{i}$

where women on board (womboard) is the dependent variable, women in parliament (womparly), the logarithm of GDP per capita (lngdp) and religiosity are endogenous regressors and masculinity (mascul) is a control variable that is taken as exogenous. As pointed out above, our independent variables are potentially endogenous, that is they may be systematically related to unobserved causes of the dependent variable, in this case, the proportion of women on boards. Violations of this sort commonly occur when factors related to independent variables, that predict outcome, are omitted from the regression model or when the independent variables themselves are measured with error (Woodridge, 2002). Of course, two-way causation is yet another condition but not the only concern.

We thus used the 2SLS estimator or the instrumental variable (IV) method, an econometric method which is useful to purge coefficients of endogeneity bias (Baum, Schaffer, \& Stillman, 2010) due to common methods, measurement error or simultaneity (Antonakis, et al., 2010). 
To use an IV method, the first step is to identify a set of variables that are exogenous and that do not depend on other variables or disturbances in the system of equations (Antonakis, Bendahan, Jacquart \& Lalive, 2010). They should also be sufficiently strongly related to the problematic endogenous covariates (Bollen, 2012).Moreover, the relationship between IVs and explanatory variables must be justified by economic theory, passing the 'theoretical overidentification' test before an empirical one (Antonakis, et al., 2010: 1104). Indeed, scholars (Antonakis, et al., 2010; Reeb, Sakakibara \& Mahmood, 2012) contend that identifying suitable instruments that satisfy the conditions of relevance and exogeneity is the biggest challenge in applying the IV method.

Once suitable instruments have been identified, the next step is to estimate the coefficients in the regression model using two-stage least squares (2SLS) or similar estimation methods. In this study we use 2SLS to estimate the coefficients in the regression model shown above. 2SLS allows for consistent estimation of simultaneous equations where one or more predictors are endogenous. This is because it handles endogeneity resulting from omitted variables, measurement error, simultaneity, and common method bias (Antonakis et al., 2010; Cameron \& Trivedi, 2005; Greene, 2008)

\section{Instrumental variables}

We identified instrumental variables for the three explanatory variables. For the explanatory variable-women in parliament, we use four instrumental variables namely proportional representation, political quotas, ethnic and linguistic fractionalization and number of years since first woman was elected to parliament.

We provide the rationale for each of these instruments. First, political scientists accept the hypothesis that the presence of a proportional representation 
system promotes female office-holding (Rule, 1987), since the system correlates the number of seats won by a political party with the number of votes cast for their party. In proportional representation systems, citizens vote for a party's list rather than individual candidates, suggesting that women need not stand alone to achieve political office (Paxton, 1997), hence no bias attributable to gender. Second, gender political quotas have the guarantee that a certain proportion of women will be appointed members of parliament (Tripp \& Kang, 2008). We, therefore, expect both proportional representation and political quotas to have a positive impact on the number of female members of parliament.

Proportional representation equals one for each year in which candidates were elected using a proportional representation system; equals zero otherwise; averaged for the years 1975-2000. This historical data, taken from Beck, Clarke, Groff, Keefer, $\&$ Walsh (2001), cannot be changed by voting choices of the period 2007-2013, the sample period of this study.

Fractionalization measures are based on the probability that two randomly drawn individuals (from a country) are not from the same group (ethnic) or do not speak the same language (linguistic). Both ethnic (ethnicfrac) and linguistic (linguifrac) fractionalization variables are drawn from Alesina, Devleeschauer, Easterly, Kurlat \& Wacziarg (2003), and refer to the situation in the late 1980s and early 1990s. Scholars argue that highly fragmented countries are more likely to affect the composition and strength of political institutions such as parliament and government (Boubakri, Mansi \& Safar, 2013). We argue that countries that are highly fractionalized, both from an ethnic and linguistic points of view, have over the years learnt to accept and to handle diversity. Such countries would, therefore, be more accepting of yet another form of diversity: gender. We, therefore, expect a positive 
association between ethnic and linguistic fractionalization on one side and the proportion of female members of parliament on the other. Having been collected in the 1980s -1990s and the fact that the fragmentation of societies on the basis of ethnicity and language cannot be changed by the dynamics of board gender parity in recent years, suggest that these instruments are exogenous.

An additional instrument for women in parliament is the number of years since the first women was elected to parliament (firstFemMP). We argue, therefore, that the presence of females in parliament is determined by institutional path dependencies (Terjesen, Aguilera \& Lorenz, 2014), indeed a function of history. Path dependence describes the 'causal relevance of preceding stages in a temporal sequence' Pierson, 2000: 252). Once a certain path has been chosen, future decisions are significantly influenced by a previous one, and more so in an incremental manner (Greener, 2005). Thus, countries with a longer history of appointing women to parliament are more likely to have more female members of parliament in our sample period. As a historical fact, defined by a specific time period, this variable cannot be influenced by the proportion of women in parliament and is free from any possible shock in the disturbances, and thus makes a good instrument.

For the explanatory variable, lnGDP, we use an exogenous geographical feature of countries (latitude) as an instrument. Latitude, the distance from the equator measured in absolute degrees, affects climate and, therefore, aspects of agricultural productivity and disease. Previous studies have shown that countries closer to the equator are less developed. Latitude has, therefore, considerable explanatory power for the log of per capita GDP (Barro \&McCleary, 2003), suggesting a positive relationship between latitude and economic growth. Latitude is completely exogenous 
and can be used as an appropriate instrument as cannot be changed by economic growth nor with any level of shock from a disturbance.

We also instrument economic growth with legal origin. We use a set of dummy variables for British, French, German, Scandinavian or Socialist legal origins. La Porta et al (1998) show that whether a country's commercial or company law is based on British, French, German, Scandinavian or Socialist legal origins is important for explaining the country's laws on creditors' rights, shareholder rights and private property rights as well as the country's level of bank and stock market development. Furthermore, Levine (1999) traces the effect of legal origin on financial development through to long-run economic growth, suggesting that legal origin influences economic growth by shaping national financial systems. The basic thrust of the legal origin theory is that common law (British), as opposed to French civil law and (to a lesser extent) German and Scandinavian civil law, is associated with more orientation towards institutions of the market instead of state intervention. According to studies based on this theory, common law countries tend to be economically more developed. Legal origin is a historical and static variable, reflecting the old age legal practices and thus today's economic growth does not determine a country's legal origin.

For the explanatory variable-religiosity, we use two instrumental variables namely state regulation of religion and religious pluralism. An important theory of religiosity is the religion-market model (Barro \& McCleary, 2003). According to this theory, religiosity depends on government intervention, including the regulation of the religion market by the state. Such an approach reduces the creativity and freedom of religious beliefs to spread and thus should have a negative impact on religiosity. State regulation (value 1 and 0 otherwise) refers to a situation in which the state appoints or approves church leaders. This designation comes from discussions in Barrett, (1982) 
and Barrett, Kurian and Johnson (2001) and typically applies in the late 1970s. Data on state regulation is taken from Barro and McCleary (2003).

Religious pluralism, measured by an index of the diversity of religions that exist in a country, is an attitude or policy regarding the diversity of religious belief systems co-existing in society. Early scholarly work based on the secularization hypothesis (Hume, 1757; Berger, 1967) provides the view that having more religious worldviews makes them common thus more human and less divine (Berger, 1967). While this may increase religious participation (the number of people attending churches, temples, synagogues, etc) however, it may lead to less religiosity (the number of people who are religious irrespective of attending a place of worship or not) in society. We, therefore, expect religious pluralism, as an instrumental variable, to have a negative impact on religiosity. Data on religious pluralism is taken from Barro and McCleary (2003). This data, like that on state regulation is in many ways historical, applying in the late 1970s, and thus makes both instrumental variables exogenous.

\section{Results}

The means, standard deviations and correlations among the study variables are presented in Table 2. The average for the proportion of women on boards across the 45 countries in our sample is $9.24 \%$, while that of women in parliament is higher at $22.77 \%$. The average for religiosity is $59.68 \%$. Correlations among the variables are generally modest.

\section{Insert Table 2 about here}

As explained above, we tested the hypotheses using ivregress of STATA to obtain 2SLS estimates. The results of the tests are shown in Tables 3 and 4. As suggested by several scholars (e.g., Antonakis et al., 2010; Larcker \& Rusticus, 
2010), we report both the OLS and the 2SLS results. From Table 3, Model 1 shows OLS results. The coefficients for women in parliament $(\beta=.25, p<.001)$ and religiosity $(\beta=-.07, p<.001)$ are as predicted. On average, a $1 \%$ increase in the number of women in parliament would translate to a $0.25 \%$ increase in the number of female directors on the board. On the other hand, a $1 \%$ increase in religiosity in a given country would lead to a decrease in the number of female directors by $0.07 \%$. However, from the OLS results there is no support for the hypothesis that economic development is related to women on boards.

Turning to the 2SLS estimation of the same equation, we start by explaining tests on the suitability of the instruments by (1) making reference to the significance of instrumental variables, in first-stage regressions, that predict endogenous variables, (2) testing whether 2SLS is the preferred method to OLS by showing tests of endogeneity (Hausman test), (3) using the score chi square (Sargan) statistic to validate the exogeneity of instruments (test of over-identification) and (4) reporting the first-stage F-statistic.

Models 2, 3, 4 and 5 report the 2SLS results. Models 2, 3, and 4 report first stage estimations, where women in parliament, lngdp and religiosity are respectively taken as endogenous regressors. Starting with the instruments for the variable, women in parliament, the coefficients on proportional representation $(\beta=7.61, p<.001)$, on the period since the first women was elected to parliament $(\beta=.13, p<.1)$ and on linguistic fractionalization $(\beta=9.10, p<.1)$ are all positive and significant as expected.

The first instrument for economic development, latitude, is positive and significant $(\beta=.03, p<.001)$ as expected. As instruments, legal origins are significant and positively related to economic development with varying coefficient sizes. 
Specifically, British $(\beta=2.21, p<.001)$, French $(\beta=1.42, p<.001)$, German $(\beta$ $=1.48, p<.001)$, and Scandinavian $(\beta=1.61, p<.05)$

As instruments, religious pluralism $(\beta=-39.91, p<.05)$ and state regulation $(\beta$ $=-19.32, p<.05)$ are both negative and significantly correlated to the dependent variable religiosity as expected.

We also carried out Wu-Hausman test for each of the endogenous regressors based on their respective instruments (results shown in Table 3 under the respective variables). The endogenous regressor women in parliament (womparly) $\left[\chi^{2}(1)=4.40\right.$, $p=.04]$ is endogenous, while economic freedom (lngdp) $\left[\chi^{2}(1)=.06, p=.81\right]$ and religiosity $\left[\chi^{2}(1)=1.58, p=.22\right]$ are both shown as exogenous.

While these tests for single endogenous regressors are indicative of the strengths and relevance of the instruments used, joint tests including all variables and their respective instruments tend to provide a better explanation for the state of variables and for the suitability of their instruments. We, therefore, turn to results for the full model or joint test, i.e. in the second stage of the 2SLS.

Contrasting the results of the second-stage regression with OLS estimation, the $\mathrm{Wu}$-Hausman test, for the full model, rejects the null that there is no endogeneity problem with OLS estimation $\left[\chi^{2}(3)=3.37, \mathrm{p}<.05\right]$, suggesting that the 2 SLS estimation is preferred to the OLS estimation.

Using the Sargan test, we then examined the veracity (over-identification restriction) of the 2 SLS model to ensure that the excluded instruments from the equation do not correlate with the disturbance of the dependent variable. The null hypothesis for the Sargan test is that the instruments are exogenous, i.e. uncorrelated with the error term. Thus, if the Sargan statistic is insignificant, we fail to reject the null hypothesis. As shown in Model 5 the Sargan test for excluded instruments 
indicate that the model constraints were tenable $\left[\chi^{2}(9)=13.54, p=.14\right]$, suggesting that the instruments as a group are exogenous. A post-estimation first-stage F-statistic test result of 22.46, $p<.001$, suggests that the instruments are not weak.

\section{Insert Table 3 about here}

Compared to the OLS estimates, discussed above, coefficients from 2SLS trend in the same direction, however, they are larger. For example, in Hypothesis 1, we proposed that the proportion of women in parliament positively impacts on the prevalence of women on boards of directors. As predicted, the coefficient for this variable is significantly positive $(\beta=.42, p<.001)$. On average, a $1 \%$ increase in the proportion of women in parliament increases the number of female directors on the board by $0.42 \%$.

In Hypothesis 2, we proposed that economic development positively impacts on the prevalence of female directors on boards. There is no support for this hypothesis as the coefficient for economic development is not significant.

In Hypothesis 3, we proposed that religious beliefs negatively impact on the prevalence of female directors on boards. As we predicted, religiosity has a negative and significant impact on female board appointments $(\beta=-0.12, p<0.05)$. This suggests that a $1 \%$ increase in religiosity in a given country would lead to a decrease in the number of female directors by $0.12 \%$.

Shea's Adjusted R-square results for the independent variables are reasonably high at $36 \%, 35 \%$ and $27 \%$ for women in parliament, economic freedom and religiosity respectively.

We reran the tests, controlling for regional effects, as shown in the equation below. Womboard $_{i}=\beta_{0}+\beta_{1}$ womparly $_{i}+\beta_{2} \operatorname{lnGDP}_{i}+\beta_{3}$ religiosity $_{i}+\beta_{4}$ mascul $_{i}+$ Region $+e_{i}$ 
Results from these tests are not significantly different from those reported in Table 3. We thus carried out further post-estimation tests (testparm in Stata) to establish the relevance of regional effects in our model. Results show that, for this study, regional effects do not matter for both $\operatorname{OLS}[F(5,35)=0.38, p>F=.86]$ and $2 \operatorname{SLS}\left[\chi^{2}(5)=2.74, p>\chi^{2}=.74\right]$.

\section{Discussion and conclusion}

The starting point of this study is that people in a society observe the activities of men and women and form corresponding beliefs about their psychological attributes. From the different activities of the sexes, they infer gender stereotypesshared expectations that women and men are intrinsically different. Guided by gender role beliefs that are shared within a society, citizens are socialized for the skills, traits, and preferences that support their society's division of labor. This, we argue, could potentially explain the limited number of female directors on boards across societies. However, some countries have higher proportions of female directors than others, a situation we attribute to the variation of national social institutions. The study, thus, examines the social and economic factors that promote or inhibit the appointment of women to corporate boards of directors.

First, we find that the representation of women in parliament impacts positively on the prevalence of women on boards. Drawing on social role theory, we argue that this finding explains that the presence of female directors in other key societal institutions helps to reduce traditional gender stereotypes, leading to acceptance of women beyond the politics. The presence of women in parliament and, by extension, in government could lead not only to acceptance of equal gender roles by both sexes, but could also motivate women to aspire for higher positions in several 
other sectors including in business. The implication for this finding is that there is need to improve on the social institutions that promote the appointment of female directors to boards. For example, mechanisms that help improve the proportion of female members of parliament such as proportional representation and political quotas for female seats in parliament have an indirect influence on the proportion of female directors, and yet these, as a starting point, may be far easier to achieve. In that regard, more studies on other areas that may have impact on board composition or on the determinants of the same, such as on the proportion of women in the workforce or women in management, are necessary.

The second hypothesis, that predicts a positive causal effect of economic freedom on the proportion of female directors, is not significantly supported. This lack of support could be explained by the fact that there are some developed countries with low levels of female representation (e.g., Japan) and some with high levels of female representation (e.g., Norway). The same could be said about countries with low levels of development.

The third hypothesis, also drawing on social role theory, emphasizes that religion encourages and reinforces values that are consistent with traditional gender roles. Unlike other social institutions discussed in this paper, therefore, religiosity has a negative effect on the prevalence of women on boards, and such was our hypothesis. This hypothesis was supported. While it is easier to change the other social institutions, changing attitudes that emanate from cultural institutions such as religion is difficult to achieve. As such, understanding religious dynamics in society is a central task of studies on gender, in general, and on women on boards, in particular. The long arm of the Catholic church's opposition to birth control, for example, demonstrates the power of religion in enforcing traditional gender roles. 
Several other messages, consistent with dominant cultural injunctions are observable across religious groups. Moreover, religion adds to these injunctions the message that they are natural and part of the universe, serving as an important vehicle for the internalization of cultural codes and at the same time making them more rigid and difficult to alter. In the context of this study, religion plays a key role in the dynamics of women's lack of representation on boards, and could potentially be used to change this situation, however, difficult. It is, therefore, important not only to understand the complexities of the relationship between religion and culture but to change the way world religions work in order to achieve gender parity in corporate boards and beyond.

Drawing on a key societal lens i.e. social role theory and recognizing the role of social institutions in either upholding or discouraging gender stereotypes, the study demonstrates the salience of the institutional environment in understanding board gender diversity, offering a number of contributions. First, this paper contributes to the growing corporate governance literature on female top executive leadership by introducing theoretical perspectives from social psychology and gender studies to frame the analysis - as called for by various researchers (e.g., Adams \& Flynn, 2005; Terjesen et al., 2009).

Second, drawing on corporate governance, religious, economic and gender studies, this paper provides an explanation for the current state of board gender diversity and insights to gender role attitudes in a relatively large number of countries. Moreover and relatedly, a further contribution beyond the substantial findings is that this study is one of the first to use a 2SLS procedure to identify institutional determinants of female board appointments. To our knowledge, this statistical approach, that ensures consistency of estimates in the face of endogeneity, has not been 
used in research on female board appointments, reducing confidence in their causal claims. We, therefore, heed recent calls by scholars (Antonakis et al., 2010; Larcker \& Rusticus, 2010; Reeb et al., 2012) who urge researchers to take endogeneity problems more seriously.

Third, this study provides enhanced understanding of the particular institutional forces that impede or facilitate women's participation in corporate leadership in a number of countries, including non-Western societies. Such knowledge assists policy makers and development workers (e.g. from the UN) to craft programs and policies that effectively address gender equality in general and women participation in corporate affairs in particular. Moreover, such knowledge could help firms that operate in specific countries to understand the dynamics of local environments on matters that concern their practices on board composition and equal opportunities.

Indeed, this research has implications for organizational leaders. To start with, the country variables investigated in this study are easily observable and measurable, and, therefore, provide important insights for managers. For companies that decide to operate in specific countries, setting up their headquarters there, we consider that managers could react to institutional contexts that are conducive to non-acceptance of gender diversity on boards. Based on our results they could decide to enter countries with favorable institutions with greater possibility of utilizing both female and male talent on their boards. Alternatively, they may enter countries with institutional barriers and then utilize female talent as a competitive advantage, since on average many firms will not be inclined to appoint female directors.

Moreover, while companies may not change the country's institutions, they may draw up internal procedures and practices that may improve the position of 
women not only for the sake of board appointments but for motivating female employees in general.

We also consider that our paper has implications for policy makers. For example, the fact that political office by women encourages more female board appointments suggests that governments may need to examine their political policies, if they are to achieve greater female board presence. As such, governments with fewer women members of parliament or in other public social spheres may come up with policies that encourage or facilitate gender parity in such areas. Such efforts may include legislating in favor of women empowerment, alongside targeted training programs to ensure that women succeed in these roles. Moreover, since societies that are highly religious are less likely to achieve board gender parity, we suggest that policy makers should push for a mandatory approach to female board appointments, such as the use of board quotas, indeed, a current argument in governance studies (Tejersen et al., 2014).

\section{Limitations and areas for future research}

Notwithstanding the timeliness of this research and the contributions discussed above, we acknowledge a few limitations of this study. First, while we use data that is sufficiently rich, and from reliable sources, to test our hypotheses, secondary data have some obvious disadvantages, as we did not have full control of sample selection or the development of our dependent variable measure. Despite the use of a strong statistical corrective technique in IV estimation, future studies could provide an alternative approach based on interviews, surveys and case studies. Second, as is common in empirical research, we cannot tell exactly whether our variables measure what we think they do. For example, we did not consider the specific aspects of religiosity to be able to determine the exact and fine-grained effect of religion on the 
presence of women on corporate boards. Future studies could distinguish the types of religious affiliation and their respective effect on female board appointments.

Third, at the center of the discussion between religion and gender, in general, and female directors, in particular, is the issue of power. Both religion and gender are centrally implicated in unequal distributions of power, and that their interplays serve and seek to reinforce existing distributions of power or to change them - in various ways and by various means. Future studies could explore power as a key intervening variable between religiosity and the appointment of female leaders.

Moreover, the institutional context of our study is limited to only forty-five countries. Although the sample has countries from every region of the world and the issues considered are universal in nature (e.g., religion), undergirded by a social psychological lens in social role theory, suggesting a reasonable level of the generalizability of our findings, however, the regional representation is not evenly distributed. As country data on board composition continues to get better in more countries, further studies could benefit from larger samples.

While this paper focuses on issues of gender, many of the arguments made in it may also apply to other minority groups with diverse backgrounds (e.g., race or ethnicity, sexual orientation, disability, or age). As is well documented, members of these groups are also disadvantaged due to their group's low social status (e.g., Lorenzi-Cioldi, 2006) and this may extend to cases of lower representation in corporate leadership (Catalyst, 2007). Moreover, in many national and organizational contexts, these groups of minorities are also likely to be perceived as atypical leaders.

In conclusion, this paper has provided factors that explain the variation of female board appointments across countries. Being part of the general theme of gender equality and the attendant benefits of diversity in corporations, the presence of 
females on boards, as a study area, continues to be of great importance. A central theme in this paper is that the lack of female board members resides in differences in societal roles that lead men and women to demonstrate and value different types of interpersonal behavior. As such corporate leadership through the institution of the board is considered as the preserve of men. This paper provides the thesis that as a social construct, these gender role stereotypes can be better understood by examining the social institutions that potentially uphold or minimize this perception. Such factors include the proportion of women in government/parliament, economic development and religiosity. The study finds support for the hypotheses that the presence of more female members in parliament increases female board appointments and that more religious societies tend to have fewer females on corporate boards.

\section{Acknowledgements}

We are grateful to the Associate Editor, Professor John Antonakis and three anonymous reviewers for their invaluable comments and suggestions that led to significant improvement of this paper. We are also grateful to Joao X, Regina Frank and Ellen Chizema for a number of conversations on the theme of women empowerment and indeed their noticeable absence in key leadership positions. 


\section{References}

Adams, S. M., \& Flynn, P.M. (2005). Local knowledge advances women's access to corporate boards. Corporate Governance: An International Review, 13(6): 836-846.

Aguilera, R.V., \& Jackson, G. (2003). The cross-national diversity of corporate governance: Dimensions and determinants. Academy of Management Review, 28(3): 447-465.

Alesina, A., Devleeschauer, A., Easterly, W., Kurlat, S., \& Wacziarg, R. (2003). Fractionalization. Journal of Economic Growth, 8(2): 155-194.

Antonakis, J., Bendahan, S., Jacquart, P., \& Lalive, R. (2010). On making causal claims: A review and recommendations. The Leadership Quarterly, 21(6): 1086-1120.

Banaszak, L., \& Plutzer, E. (1993). Contextual determinants of feminist attitudes: National and subnational influences in Western Europe. American Political Science Review, 87: $147-157$.

Bandura, A. (1977). Social learning theory. New York: General Learning Press.

Barrett, D.B. (1982). World christian encyclopedia, $1^{\text {st }}$ ed. Oxford: Oxford University Press.

Barrett, D.B., Kurian, G.T., \& Johnson, T.M. (2001). World christian encyclopedia, ${ }^{2 \mathrm{nd}} \mathrm{ed}$. Oxford: Oxford University Press.

Barro, R.J., \& McCleary, R.M. (2003). Religion and economic growth. American Sociological Review, 68: 760-781.

Beck, T., Clarke, G., Groff, A., Keefer, P., \&Walsh, P. (2001). New tools in comparative political economy: The database of political institutions. World Bank Economic Review, 15(1): 165-176.

Bendroth, M. L. (1993). Fundamentalism and gender: 1875 to the present. New Haven: Yale University Press.

Berger, P.L. (1967). The sacred canopy: Elements of a sociological theory of religion. Garden City NJ: Doubleday. 
Betz, N.E., \& Fitzgerald, L.F. (1987). The career psychology of women. New York: Academic Press.

Bollen, K. A. (2012). Instrumental variables in sociology and the social sciences. Annual Review of Sociology, 38(1): 37-72.

Boubakri, N., Mansi, S., \& Saffar, W. (2013). Political Institutions, connectedness and corporate risk taking. Journal of International Business Studies, 44: 195-215.

Browne, K. (1999). Divided labors: An evolutionary view of women at work. New Haven, CA: Yale University Press.

Bullough, A., Kroeck, K.G., Newbury, W., Kundu, S.K., \& Lowe, K.B. (2012). Women's political leadership participation around the world: An institutional analysis. The Leadership Quarterly, 23: 398-411.

Cameron, A. C., \& Trivedi, P. K. (2005). Microeconometrics: Methods and applications. New York: Cambridge University Press.

Catalyst, (2007). Catalyst census of women board directors of the Fortune 500.

Carter, D. A., D'Souza, F., Simkins, B. J., \& Simpson, W. G. (2010). The gender and ethnic diversity of US boards and board committees and firm financial performance. Corporate Governance: An International Review, 18(5): 396-414.

Conyon, M.J., \& Mallin, C. (1997). Women in the boardroom: Evidence from large UK companies. Corporate Governance: An International Review, 5: 112-117.

Eagly, A. H. (1987). Sex differences in social behavior: A social-role interpretation. Hillsdale, NJ: Erlbaum.

Eagly, A. H. (2009). The his and hers of prosocial behavior: An examination of the social psychology of gender. American Psychologist, 64(8): 644-658.

Eagly. A.H., \& Johannesen-Schmidt, M.C. (2001). The leadership styles of women and men. Journal of Social Issues, 57: 781-797.

Eagly, A.H., \& Karau, S.J. (2002). Role congruity theory of prejudice toward female leaders. Psychological Review, 109: 573-598.

Eagly, A.H., \& Wood, W. (2012). Social role theory. In P. van Lange, A. Kruglanski, \& E. T. Higgins (Eds.), Handbook of theories in social psychology (Vol. 2, pp. 458-476). Thousand Oaks, CA: Sage Publications.

Eyring, A., \& Stead, B.A. (1998). Shattering the glass ceiling: Some successful corporate practices. Journal of Business Ethics, 17: 245-251.

Fouts, H.N. (2008). Father involvement with young children among the Aki and Bofi foragers. Cross-Cultural Research, 42: 290-312. 
Glick, P., \& Fiske, S.T. (2001). An ambivalent alliance: Hostile and benevolent sexism as complementary justifications for gender inequality. American Psychologist, 56: 109118.

Goldberg, S. (1993). Why men rule: A theory of male dominance. Chicago: Open Court.

Greene, W. H. (2008). Econometric analysis (6th ed.). Upper Saddle River, NJ: PrenticeHall.

Greener, I. (2005). The potential of path dependence in political studies. Politics, 25: 62-72. Greenhaus, J.H., \& Parasuraman, S. (1999). Research on work, family, and gender: Current status and future directions. In G. N. Powell (Ed.), Handbook of gender and work (pp. 391-412). Thousand Oaks, CA: Sage.

Grosvold, J., \& Brammer, S. (2011). National institutional systems as antecedents of female board representation: An empirical study. Corporate Governance: An International Review, 19(2): 116-135.

Hall, P.A., \& Soskice, D. (2001). Varieties of capitalism in the institutional foundations of comparative advantage. Oxford: Oxford University Press

Harris, R., \& Firestone, J. (1998). Changes in predictors of gender role ideologies among women: A multivariate analysis. Sex Roles, 38:239-52.

Heilman, M.E. (2001). Description and prescription: How gender stereotypes prevent women's ascent up the organizational ladder. Journal of Social Issues, 57, 657-674.

Hillman, A. J., Shropshire, C., \& Cannella, A.A. (2007). Organizational predictors of women of corporate boards. Academy of Management Journal, 50: 941-952.

Hofstede, G. (1998). Religion, masculinity and sex. In G. Hofstede \& Associates (Eds.), Masculinity and femininity: The taboo dimension of national cultures (pp.192-209). Thousand Oaks, CA: Sage.

Hofstede, G. (2001). Culture's consequences: Comparing values, behaviors, institutions and organizations across nations. Thousand Oaks CA: Sage Publications.

Hume, D. (1757). The natural history of religion. Oxford: Oxford University Press.

Iannaccone, L.R. (1991). The consequences of religious market structures: Adam Smith and the economics of religion. Rationality and Society, April: 156-177.

Ingelhart, R., \& Norris, P. (2003). Rising tide. Gender equality and cultural change around the world. Cambridge: Cambridge University Press.

Jackson, R.M. (1998). Destined for equality: The inevitable rise of women's status. Harvard: Harvard University Press. 
Jackson, G., \& Deeg, R. (2008). Comparing capitalisms: Understanding institutional diversity and its implications for international business. Journal of International Business Studies, 39: 540-561.

Jost, J.T. (2006). The end of the end of ideology. American Psychologist, 61: 651-670.

Jost, J.T., \& Kay, A.C. (2005). Exposure to benevolent sexism and complementary gender stereotypes: Consequences for specific and diffuse forms of system justification. Journal of Personality and Social Psychology, 88, 498-509.

Kenworthy, L., \& Malami, M. (1999). Gender inequality in political representation: A worldwide comparative analysis. Social Forces, 78(1): 235-269.

Kilbourne, B., \& England, P. (1996). Occupational skill, gender, and earnings. In P. Dubeck \& K. Borman (Eds.) Women and work: A handbook. New York: Garland.

Kirchmeyer, C. (2002). Gender differences in managerial careers: Yesterday, today and tomorrow. Journal of Business Ethics, 37: 5 - 24

Koenig, A. M., Eagly, A. H., Mitchell, A. A., \& Ristikari, T. (2011). Are leader stereotypes masculine? A meta-analysis of three research paradigms. Psychological Bulletin, 137: $616-642$.

Kostova, T. (1997). Country institutional profile: Concepts and measurement. Best Paper Proceedings of the Academy of Management: 180-184.

Kostova, T. (1999). Transnational transfer of strategic organizational practices: A conceptual perspective. Academy of Management Review, 24: 208-324.

Larcker, D. F., \& Rusticus, T. O. (2010). On the use of instrumental variables in accounting research. Journal of Accounting and Economics, 49: 186-205.

Lindsey, L.L. (2005). Gender roles - A sociological perspective. Upper Saddle River, NJ: Prentice Hall.

Lorenzi-Cioldi, F. (2006). Group status and differentiation. In T. Postmes \& J. Jetten (Eds.), Individuality and the group (94-115). Sage: London.

Matland, R.E. 1998. Women's legislative representation in national legislatures: a comparison of democracies in developed and developing countries. Legislative Studies Quarterly, 28: 109-125.

McKinsey \& Company, (2007). Gender diversity, a corporate performance driver, Women Matter, 1-25.

Munshi, K. (2003). Social learning in a heterogeneous population: technology diffusion in the Indian Green Revolution. Journal of Development Economics, 73: 185-213. 
Nielsen, S., \& Huse, M. (2010). The contribution of women on boards of directors: Going beyond the surface. Corporate Governance: An International Review, 18(2): 136-148.

OECD, (2009). Gender and sustainable development: Maximizing the economic, social, and environmental role of women. OECD: Paris.

Paxton, P. (1997). Women in national legislatures: A cross-national analysis. Social Science Research, 26: 442-464.

Peterson, C., \& Philpot, J. (2007). Women's roles on U.S. Fortune 500 boards: Director expertize and committee memberships. Journal of Business Ethics, 72: 177-196.

Pierson, P.(2000). Increasing returns, path dependence, and the study of politics. American Political Science Review, 94: 251-267.

Reeb, D., Sakakibara, M., \& Mahmood, I. P. (2012). From the Editors: Endogeneity in international business research. Journal of International Business Studies, 43(3): 211218.

Richerson, P. J., \& Boyd, R. (2005). Not by genes alone: How culture transformed human evolution. Chicago: University of Chicago Press

Ridgeway, C. (2006). Linking social structure and interpersonal behavior: A theoretical perspective on cultural schemas and social relations. Social Psychology Quarterly, 69:5-16.

Ruigrok, W., Peck, S., \& Tacheva, S. (2007). Nationality and gender diversity on Swiss corporate boards. Corporate Governance: An International Review, 15: 546-557.

Rule, W. (1987). Electoral systems, contextual factors and women's opportunity for election to parliament in twenty-three democracies. The Western Political Quarterly, 40: 477498.

Sayer, L., Cohen, P.N., \& Casper, L. (2004). Women, men and work. In The American People: Census 2000. Russell Sage Foundation \& Population Reference Bureau.

Scott, R. (1995). Institutions and organizations. Thousand Oaks, CA: Sage Publications.

Seierstad C., \& Opsahl, T. (2011). For the few not the many? The effects of affirmative action on presence, prominence, and social capital of female directors in Norway. Scandinavian Journal of Management, 27 (1): 44-54.

Seierstad, C., \& Healy, G. (2012). Women's equality in the Scandinavian academy-a distant dream? Work, Employment and Society, 26(2): 296-313.

Skjeie, H. (1991). The rhetoric of difference: On women's inclusion into political elites. Politics and Society, 19(2): 233-63. 
Singh, V., \& Vinnicombe, S. (2004). Why so few women in top UK boardrooms? Evidence and theoretical explanations. Corporate Governance: An International Review, 12: 479-488.

Spence, J. T., \& Buckner, C. E. (2000). Instrumental and expressive traits, trait stereotypes, and sexist attitudes. Psychology of Women Quarterly, 24: 44-62.

Stark, R., \& Bainbridge, W.S. (1987). A theory of religion. New York: Lang.

Stock, J.H., \& Yogo, M. (2002). Testing for weak instruments in linear IV regression. In D.W.K. Andrews \& J.H. Stock (Eds.), Indentification and infererence for econometric models: Essays in honor of Thomas Rothenberg (pp.80-108). Cambridge: Cambridge University Press.

Tennie, C., Call, J., \& Tomasello, M. (2009). Ratcheting up the ratchet: on the evolution of cumulative culture. Philosophical Transactions of the Royal Society of Biological Sciences, 364: 2405-2415

Terjesen, S., Aguilera, R.V., \& Lorenz, R. (2014). Legislating a woman's seat on the board: Institutional factors driving gender quotas for boards of directors. Journal of Business Ethics, 50(2): 177-186.

Terjesen, S., \& Singh, V. (2008). Female presence on corporate boards: A multi-country study of environmental context. Journal of Business Ethics, 83(1): 55-64.

Terjesen, S., Sealy, R., \& Singh, V. (2009). Women directors on corporate boards: A review and research agenda. Corporate Governance: An International Review, 17: 320-333.

Tripp, A.M., \& Kang, A. (2008). The global impact of quotas: On the fast tract to increased female legislative representation. Comparative Political Studies, 41(3): 338-361.

Turner, J.H. 1997. The institutional order. New York: Addison Wesley Educational Publishers.

Turner, J.C., Hogg, M.A., Oakes, P.J., Reicher, S.D., \& Wetherell, M.S. (1987). Rediscovering the social group: A self- categorization theory. Oxford: Blackwell. van Knippenberg, A., van Twuyver, M., \& Pepels, J. (1994). Factors affecting social categorization processes in memory. British Journal of Social Psychology, 33: 419431.

VanYperen, N.W., \& Buunk, B.P. (1991). Equity theory, exchange orientation and communal orientation from a cross-national perspective. Journal of Social Psychology, 131: 520.

WIN-Gallup International, (2012). Religiosity and Atheism Index. 1-25. 
Woodhead, L. (2006). Sex and secularization. In G. Loughlin (ed.), Queer theology:

Rethinking the western body (pp. 230-234). Oxford: Blackwell.

World Bank. (2007). Doing business report: Comparing regulations in 178 countries.

Washington D.C.: The World Bank.

Todd, M., Johnson, M., \& Grim, B. J. (eds.) (2003). World Religious Database.

Table 1: Distribution of countries by region

\begin{tabular}{lc}
\hline Region & $\begin{array}{c}\text { Number of } \\
\text { Countries }\end{array}$ \\
\hline Asia & 13 \\
Europe & 16 \\
Eastern Europe & 4 \\
South America & 4 \\
North America & 3 \\
Africa \& Middle East & 5 \\
& \\
\hline Total & $\mathbf{4 5}$ \\
\hline
\end{tabular}


Table 2: Means, standard deviations and correlations

\begin{tabular}{lllllll}
\hline & Mean & SD & 1 & 2 & 3 & 4 \\
\hline 1.womboard & 9.24 & 6.38 & & & & \\
2.womparly & 22.77 & 10.69 & $0.60 * *$ & & & \\
3. lngdp & 9.73 & 1.13 & $0.39 * *$ & $0.50 * *$ & & \\
4. relig & 59.68 & 26.04 & $-0.39 * *$ & -0.29 & $-0.50 * *$ & \\
5. mascul & 51.07 & 19.26 & $-0.43 *$ & -0.39 & -0.11 & -0.03 \\
\hline Notes: **p $<.05 ; * p<0.1$ & & & & &
\end{tabular}

Abbreviated variables: women on the board (womboard), women in parliament (womparly), logarithm of gross domestic product (lngdp), religiosity (relig), masculinity (mascul) 
Table 3: OLS and 2SLS regression results: Dependent variable- proportion of women on the board

\begin{tabular}{|c|c|c|c|c|c|c|}
\hline & $\frac{\text { Model } 1}{\text { OLS }}$ & $\begin{array}{l}\frac{\text { Model } 2}{\left(1^{\text {st }} \text { stage }\right)} \\
\text { womparly }\end{array}$ & $\begin{array}{l}\frac{\text { Model } 3}{\left(1^{\text {st }} \text { stage }\right)} \\
\text { lngdp }\end{array}$ & $\begin{array}{l}\text { Model } 4 \\
\left(1^{\text {st }} \text { stage }\right) \\
\text { religiosity }\end{array}$ & $\begin{array}{l}\frac{\text { Model } 5}{2^{\text {nd }} \text { Stage }} \\
2 \text { SLS }\end{array}$ & $\begin{array}{l}\text { Shea's } \\
\text { Adj R }{ }^{2}\end{array}$ \\
\hline Intercept & $\begin{array}{l}14.40 * * \\
(9.78)\end{array}$ & $\begin{array}{l}9.67 \\
(9.34)\end{array}$ & $\begin{array}{l}6.84 * * * \\
(.96)\end{array}$ & $\begin{array}{l}124.62 * * * \\
(25.55)\end{array}$ & $\begin{array}{l}26.74 * * \\
(13.53)\end{array}$ & \\
\hline womparly & $\begin{array}{l}.26^{* * * *} \\
(.09)\end{array}$ & & & & $\begin{array}{l}.42 * * * \\
(.12)\end{array}$ & .36 \\
\hline lngdp & $\begin{array}{l}-.20 \\
(.88)\end{array}$ & & & & $\begin{array}{l}-1.67 \\
(1.20)\end{array}$ & .35 \\
\hline relig & $\begin{array}{l}-.07 * * \\
(.03)\end{array}$ & & & & $\begin{array}{l}-.12 * * \\
(.05)\end{array}$ & .27 \\
\hline mascul & $\begin{array}{l}-.09 * * \\
(.04)\end{array}$ & $\begin{array}{l}-.04 \\
(.08)\end{array}$ & $\begin{array}{l}-.00 \\
(.01)\end{array}$ & $\begin{array}{l}-.24 \\
(.22)\end{array}$ & $\begin{array}{l}-.07 \\
(.04)\end{array}$ & \\
\hline polquota & & $\begin{array}{l}-4.71 \\
(3.37)\end{array}$ & $\begin{array}{l}.87 * * \\
(.35)\end{array}$ & $\begin{array}{l}9.92 \\
(9.21)\end{array}$ & & \\
\hline proprep & & $\begin{array}{l}7.61 * * * \\
(2.55)\end{array}$ & $\begin{array}{l}.21 \\
(.26)\end{array}$ & $\begin{array}{l}-15.28 * * \\
(6.96)\end{array}$ & & \\
\hline firstFemMP & & $\begin{array}{l}.13 * \\
(.07)\end{array}$ & $\begin{array}{l}-.00 \\
(.01)\end{array}$ & $\begin{array}{l}-04 \\
(.19)\end{array}$ & & \\
\hline ethnifrac & & $\begin{array}{l}.67 \\
(7.15)\end{array}$ & $\begin{array}{l}.31 \\
(.73)\end{array}$ & $\begin{array}{l}30.98 \\
(19.56)\end{array}$ & & \\
\hline linguifrac & & $\begin{array}{l}9.10 * \\
(5.93)\end{array}$ & $\begin{array}{l}-1.74 * * * \\
(.61)\end{array}$ & $\begin{array}{l}.38 \\
(16.23)\end{array}$ & & \\
\hline latitude & & $\begin{array}{l}.13 \\
(0.10)\end{array}$ & $\begin{array}{l}.03 * * * \\
(.01)\end{array}$ & $\begin{array}{l}-.76 * * * \\
(.27)\end{array}$ & & \\
\hline Leg_Brit & & $\begin{array}{l}5.47 \\
(4.87)\end{array}$ & $\begin{array}{l}2.21 * * * \\
(.50)\end{array}$ & $\begin{array}{l}-14.45 \\
(13.32)\end{array}$ & & \\
\hline Leg_Frenc & & $\begin{array}{l}8.61 * \\
(5.08)\end{array}$ & $\begin{array}{l}1.42 * * * \\
(.52)\end{array}$ & $\begin{array}{l}-7.37 \\
(13.91)\end{array}$ & & \\
\hline Leg_Germ & & $\begin{array}{l}4.79 \\
(4.89)\end{array}$ & $\begin{array}{l}1.48^{* * *} \\
(.50)\end{array}$ & $\begin{array}{l}-14.15 \\
(13.36)\end{array}$ & & \\
\hline Leg_Scan & & $\begin{array}{l}16.26^{* * *} \\
(7.33)\end{array}$ & $\begin{array}{l}1.61 * * \\
(.75)\end{array}$ & $\begin{array}{l}-20.44 \\
(20.05)\end{array}$ & & \\
\hline relplural & & $\begin{array}{l}16.39 * * \\
(7.30)\end{array}$ & $\begin{array}{l}1.78 * * \\
(.75)\end{array}$ & $\begin{array}{l}-38.91 * * \\
(19.98)\end{array}$ & & \\
\hline stateregrel & & $\begin{array}{l}.79 \\
(2.97)\end{array}$ & $\begin{array}{l}-.15 \\
(.30)\end{array}$ & $\begin{array}{l}-19.32 * * \\
(8.13)\end{array}$ & & \\
\hline $\mathrm{R}^{2}$ & .48 & .72 & .74 & .65 & \multicolumn{2}{|l|}{.41} \\
\hline Sargan & & & & & \multicolumn{2}{|c|}{$\chi^{2}(9)=13.54, p=.14$} \\
\hline Hausman & & $\chi^{2}(1)=4.40, p=.04$ & $\chi^{2}(1)=.06, p=.81$ & $\chi^{2}(1)=1.58, p=.22$ & \multicolumn{2}{|c|}{$\chi^{2}(3)=3.37, p=.03$} \\
\hline F-Statistic & & $\mathrm{F}(12,31)=5.37 * * *$ & $\mathrm{~F}(12,31)=7.29 * * *$ & $\mathrm{~F}(12,31)=4.85^{* * *}$ & \multicolumn{2}{|l|}{$22.46^{* * * *}$} \\
\hline
\end{tabular}

Notes: Standard errors in parentheses, $\mathrm{N}=45, \quad * \mathrm{p}<0.10, * * \mathrm{p}<0.05, * * * \mathrm{p}<0.001$

Abbreviated variables: women in parliament (womparly), logarithm of gross domestic product (lngdp), religiosity (relig), masculinity (mascul), political quotas (polquota), proportional representation (proprep), number of years since a female member was appointed to parliament (firstFemMP), ethnic fractionalization (enthnifrac), linguistic fractionalization (linguifrac), legal British origin , (Leg_Brit), legal French origin (Leg_Frenc), legal German origin (Leg_Germ), legal Scandinavian origin (Leg_Scan), religious pluralism (relplural), state regulation of religion (stateregrel). 